\begin{tabular}{ll}
\hline \hline MINING AND METALLURGY INSTITUTE BOR & ISSN: 2334-8836 \\
& UDK: 622 \\
\hline \hline
\end{tabular}

UDK: 678.743:666.92(045)=20

DOI:10.5937/MMEB1401057M

Slavica R. Mihajlovic ", Dragan S. Radulović, Sonja Z. Milićević, Živko T. Sekulić

\title{
APPLICATION OF LIME IN THE POLYVINYL CHLORIDE INDUSTRY ${ }^{* * *}$
}

\begin{abstract}
This paper presents the importance of limestone in a variety of industries with a special focus on the use of limestone as filler in the industry of polyvinyl chloride $(P V C)$. Of Out of all fillers, used in the industry of PVC processing, calcium carbonate type of fillers are $80 \%$. Fillers are used in order to improve various mechanical properties of polymer such as tensile and breaking properties, density, bending strength, hardness, thermal stability, viscosity and more. Latest trends of industrial development and demands of the processing industry for high quality carbonate fillers influenced the implementation process of surface modification limestone and calcite, which is the main constituent of fine micronized limestone in order to enhance its performance.
\end{abstract}

Keywords: limestone, calcite, filler, PVC

\section{INTRODUCTION}

Limestone is used in a large number of industries including the industry for processing of polyvinyl chloride (PVC). The largest application of limestone is found in the construction industry where it is used to make plaster, concrete mixtures, in manufacturing various types of cement, lime and directly in the form of various sized crushed stone. Another important user of limestone is metallurgy, where limestone used in agglomeration, in blast furnaces and the Besemer smelting process. Chemical industry also uses a significant amount of raw materials in the industrial production of nitrogen compounds, pulp, paper, soda, chlorine lime, carbide, rubber and others. In agricultural, limestone is used for neutraliza tion of acid soils, and as a feed additive. Significant amounts of limestone are used in the sugar industry, glass and ceramic industries. In many cases, particular industries have established the general standards of quality limestone, although some users set their own internal requirements.

The quality of limestone (defined chemical composition) refers to the smallest content of $\mathrm{CaO}$, or $\mathrm{CaCO}_{3}$, and maximum content of impurities and harmful components, such as $\mathrm{Fe}_{2} \mathrm{O}_{3}, \mathrm{SiO}_{2}, \mathrm{Al}_{2} \mathrm{O}_{3}, \mathrm{MgO}, \mathrm{P}_{2} \mathrm{O}_{5}, \mathrm{TiO}_{2}$, $\mathrm{MnO}, \mathrm{Cr}_{2} \mathrm{O}_{3}$ content of alkali, cement and others. The group of physical properties that determine the quality of limestone are: grain size distribution, fortress, capacity, porosity, colour, etc. Limestone, used as filler in a

\footnotetext{
* Institute for Technology of Nuclear and Other Mineral Raw Materials, Franše d'Eperea 86, 11000 Belgrade, Serbia, e-mail address: s.mihajlovic@itnms.ac.rs

** This paper is the result of research on the Project TR 34013: "Development of Technological Processes for Obtaining of Ecological Materials Based on Nonmetallic Minerals", and the Project TR 34006: "Mechano-chemical Treatment under Insufficient Mineral Resources", funded by the Ministry of Education, Science and Technological Development of the Republic of Serbia for the period 2011-2014.
} 
variety of industries, must be of high quality finely divided materials. In the products, based on limestone, the most important qualitative properties are colour (whiteness) and shine. Also, the physical structure of mineral and rock mass is an important factor, especially when considering the ability of grinding the mineral raw materials. Within these requirements, and for each purpose, or users, the appropriate standards are identified. Procedures for preparation the mineral raw materials are processed to a number of $\mathrm{Ca}$ carbonate raw materials with different chemical and mineral composition, in order to obtain a large number of products for various industries. In literature, the Ca-carbonate mineral deposits are commonly classified as the industrial mineral resources, while the geologists classify them into dolomite and limestone, [1].

\section{LIMESTONE-FILLER FOR POLYVINYL CHLORIDE}

Among many different additives that are necessary to polyvinyl chloride (PVC) in order to obtain a definitive quality product, a significant place have special additives under the name fillers for PVC. The term filler in PVC processing technology includes generally very inexpensive inorganic material, resulting in the first task, which is to reduce the cost of overall mixture, or the finished product [2]. Mineral fillers, which also include limestone, with their largest application in the industry, are just thermoplastics, especially in PVC. Industry for the production of PVC sets certain requirements in terms of quality that apply to all fillers, including the limestone: to withstand heat, pressure and mechanical stresses with no changes that accompany the processing of PVC, should be well dispersed in PVC, more white, free of impurities and foreign matter, must not act abrasive, must not contain more than $0.4 \%$ moisture, if PVC are inactive, the fillers should be emphasized, however the need for their inertness and compatibility with all additives present in the mixture.
Limestone, as well as other inorganic fillers are added to the PVC is always in the form of fine, dry powder and in the mixing step of PVC with other additives, with the aim of better and more complete homogenisation. The latest trends of industry development and requirements of manufacturing industry for high quality carbonate fillers were directed towards finding the test procedures to improve properties of limestone as filler. Filler in order to get that power will improve the mechanical properties of PVC products is done by modifying the surface of calcite, which is the main constituent of fine micronized limestone. The most commonly used reagents for modification are fatty acid salts of various fatty acids, various oils, etc., [2-5]. Limestone with surface-modified mineral calcite can be very easily dispersed in the polymer giving a homogeneous mixture. Moreover, limestone modified in any area calcite shows more improved properties as compared to lime which was not modified with the calcite namely: limestone becomes highly hydrophobic and thus water repellent and moisture which is very important for each filler; calcite surface modification significantly reduces the abrasive effect of limestone; these fillers show the improved rheological properties, higher impact resistance and better electrical properties; the use of this type of filler gets significantly better surface finished products, given the smoothness, gloss and its appearance [6]. It should be noted that all of the fillers, used in the industrial processing of PVC, $80 \%$ of total consumption are calcium carbonate type fillers.

\section{POLIVINIL CHLORIDE (PVC)}

Polyvinyl chloride (PVC) is more than 70 years one of the most important polymers whose production capacity of about $20 \%$ of the total world production of polymers. By the procedure of polymerization vinyl chloride is obtained powder from which further processing produces two types of PVC and rigid and PVC soft (flexible) PVC. Rigid PVC is obtained by processing the polymer powder without 
special additives. Sheer is a tough, tough and hard to process, but very stable on the impact of atmospheric precipitation, humidity and chemicals. It is used for example for making window frames, ca-sings, etc. Soft PVC is obtained by processing the polymer powder with the addition of plasticizers. At the same time a thick paste was obtained, which is converted by heating into a homogeneous gel. Properties of soft PVC depend on the proportion of plasticizer. It has weaker mechanical properties, less resistant to the action of heat, chemical and atmospheric precipita tions in relation to the rigid PVC, but pliable and easily processed. It is used for making insulators for cables, medical instruments, disposable tubes, gloves, etc. A transparent, soft PVC, and can be used for making transparent films, and bottles. In general, it can be said that the properties of polymer are determined by their internal material, and some of their properties are similar to the properties of solid crystalline bodies, while the other are similar to the properties of liquids. Physical and mechanical properties of rigid and soft PVC are shown in Table 1 [7].

Table 1 Physical and mechanical properties of PVC

\begin{tabular}{lccc}
\hline Property & Unit & Rigid PVC & Soft PVC \\
\hline Density & $\mathrm{g} / \mathrm{cm}^{3}$ & 1.38 to 1.55 & 1.16 to 1.35 \\
Tensile Strength & $\mathrm{MPa}$ & $40-60$ & $10-25$ \\
Extension in breaking & $\%$ & $30-70$ & $250-450$ \\
Compressive strength & $\mathrm{MPa}$ & $55-90$ & $6-12$ \\
Hardness per Shore & - & $\mathrm{D} 65-85$ & $\mathrm{~A} 40-100$ \\
Specific heat capacity & $\mathrm{J} / \mathrm{K} \mathrm{g}$ & $0.8-1.1$ & $1.3-2$ \\
Thermal Conductivity & $\mathrm{W} / \mathrm{K} \mathrm{m}$ & $(15-20) \times 10^{-4}$ & $(13-17) \times 10^{-4}$ \\
Coefficient of thermal expansion & $1 / \mathrm{K}$ & $(5-10) \times 10^{-5}$ & $(7-25) \times 10^{-5}$ \\
\hline Temperature of constant use & ${ }^{\circ} \mathrm{C}$ & $65-85$ & $50-70$ \\
\hline
\end{tabular}

PVC is produced nowadays in large quantities due to good mechanical and physical properties, as well as a diverse range of applications. PVC is non-flammable, burning in the presence of flame and chemically inert. It is compatible with many additives, including fillers plasticisers, stabilisers, lubricants and other polymers. Figure 1 shows the proportion of certain additives of polyvinyl chloride [8].

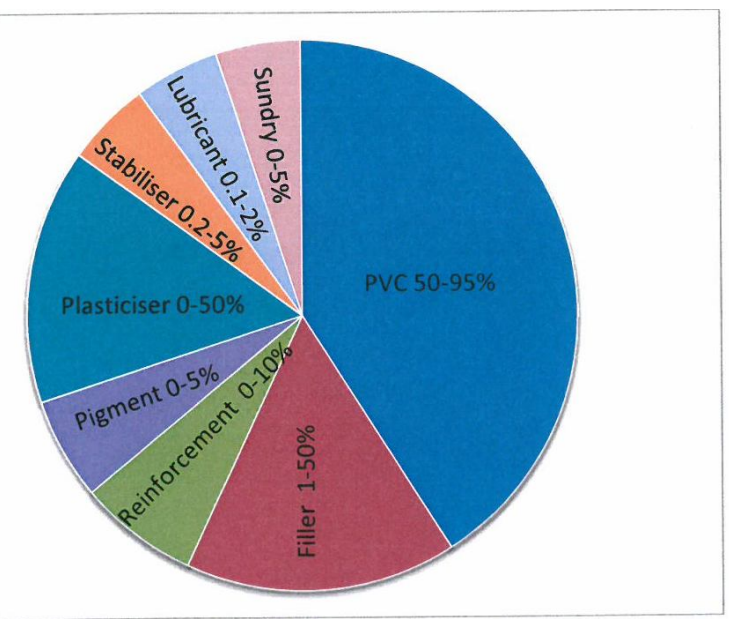

Figure 1 Content of certain adittives in the PVC mixture 
These additives allow polymer to be more easily processed by various techniques, and to obtain the stable products in degradation of certain mechanical properties.

\section{PLASTICS}

Plastics are defined polymeric materials in the process of refining. Wherein it means that the polymeric material is everything that is processed, i.e. what the final product is made. Also, the plastic masses are materials obtained on the basis of polymer, having plasticity in some condition (high-temperature conditions), and which is completely or partially lost during transition to the other temperature conditions (low temperature).
Plasticity of these materials allows them to obtain the necessary forms using the methods based on plastic deformation. Plastics are characterized that their mechanical properties are a combination of properties of solids and liquids. In the other words, they are solid materials which can be subjected to high mechanical deformations reflux [9]. Therefore, plastics today are very widely used in various industries as well as in everyday life. In particular, the increased production and use of synthetic thermo-plastics - thermoplastic (high temperature is easy to shape and retain that shape by cooling), which include PVC, as well as their use. Figure 2 shows the consumption of PVC in various industries [10].

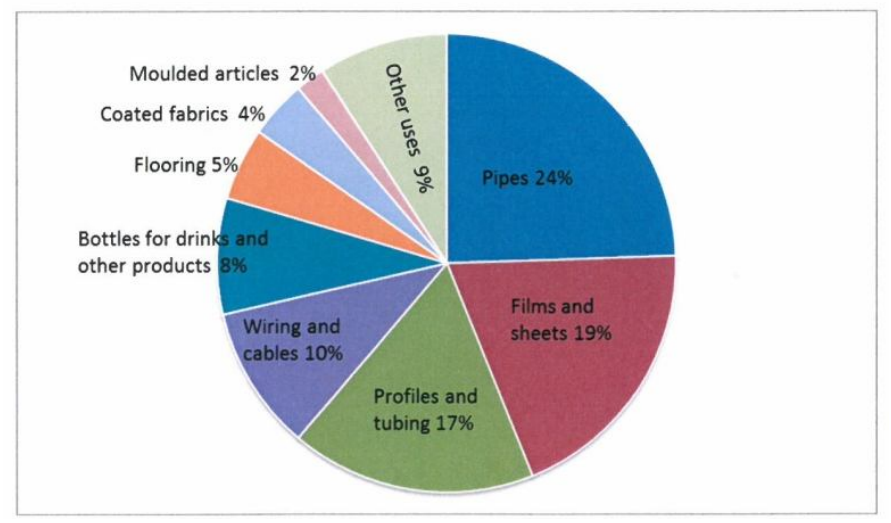

Figure 2 Consumption of PVC in various industries

Plastics can be composed only of polymer. However, in most cases the plastics are multicomponent systems (so-called polymer blends) the composition of which, in addition to the polymer, includes the following components: binder, hardener or catalyst, filler, plasticiser and colorant. Plastic material consisting of polymer with filler is the simplest kind of polymer compound, consisting of a polymer matrix (matrices) as the continuous phase and inorganic filler dispersed in the matrix. Fillers are used in order to modify various properties of polymer such as tensile properties (tensile strength and the elongation tension); breaking pro- perties (tensile strength and elongation), the density increases, the modulus of elasticity and flexural strength; it reduces the coefficient of thermal expansion and creep, increases the hardness and thermal stability, improves the surface quality of the finished product, and modifies the thermal conductivity changing the flow properties increasing the viscosity and reducing the swelling of extrudate, and it reduces the combustibility and improves the possibility of colouring plastics.

Mechanical properties of plastics are of great importance to the process of refining and defining the quality of finished 
products. When plastics are usually static testing of mechanical properties determined: tensile strength and elongation tension, tensile strength and elongation. Tensile properties are of primary importance, because they provide information on maximum allowable load to failure plastics and final rupture. The plastic mass that makes unfilled polymer, the fracture occurs at the point where the structure is the weakest, or at the point of creating the highest stress as the result of deformation. Local crack further expands throughout the material. In the example of polyvinyl chloride-free polymer as the filler, Figure 3 shows the Van der Waals bonds between two chains of PVC under the force of elongation [2].

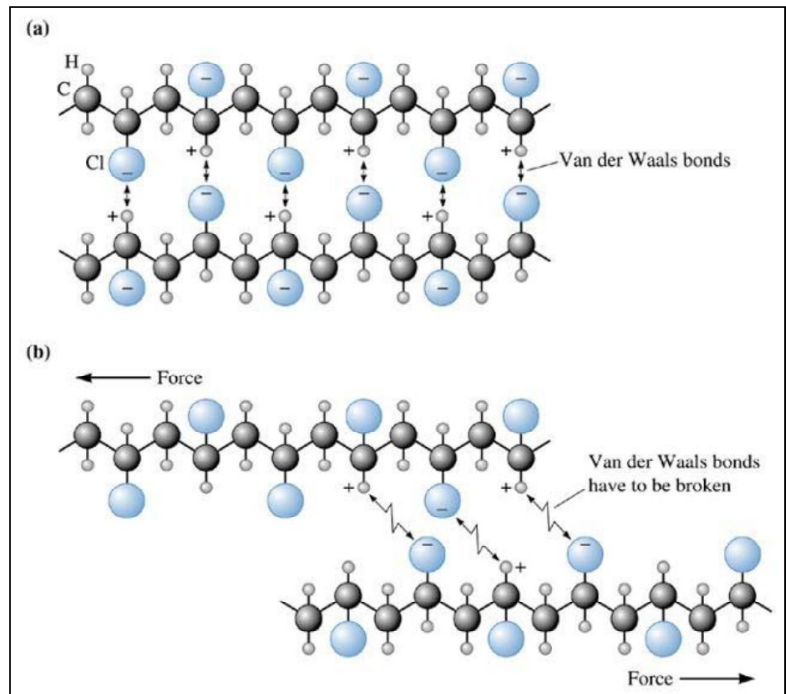

Figure 3 Scheme of molecular connections in polyvinyl chloride $(P V C)$ :

a) Van der Waals connections between two PVC chains; b) Breaking of the

Van der Waals connections between two PVC chains under the effect of tension force

In the plastic mass consisting of a polymer with filler, the fracture may begin in a matrix itself at the interface polymer/filler, or within the agglomerates formed in the filler. Tensile stress of the polymer mixture depends on its microstructure, including the interfacial border of the structure in polymer / filler, since the load is transferred from one stage to another. Also, the properties of polymer blends are determined by the certain shape and size of the filler particles and their spatial distribution in the matrix, i.e. polymer. Generally, it can be said that a fillertype calcium carbonate with their presence contributes to stronger interaction between the PVC chains. Addition of lime in the calcite which, as the dominant mineral is modi- fied with stearic acid and mixture of the polymer provides an even stronger interaction in the system of limestone or calcite PVC-stearic acid which results in improvement the mechanical properties of the final product $[2,6]$. Table 2 contains the values of some mechanical properties of the blend of PVC containing pure limestone $(\mathrm{C})$ as the filler $(\mathrm{PVC}+\mathrm{C})$ and the modified limestone (PVC+CW-1.5, and PVC+CD-3). Designation $\mathrm{W}$ refers to the "wet" modification process, D to the "dry" method, and the number represents the concentration of stearic acid which is used for modifying, expressed in $\%$. Those concentrations are taken in both processes at which there was a full coverage of minerals with stearic acid. 
Table 2 Mechanical properties of PVC blends

\begin{tabular}{lcccc}
\hline Mechanical properties & Unit & PVC+C & PVC+CW-1.5 & PVC+CD-3 \\
\hline Tensile strength & $\mathrm{MPa}$ & 52.70 & 54.20 & 53.20 \\
Breaking strength & $\mathrm{MPa}$ & 36.50 & 38.20 & 37.90 \\
Tensile elongation & $\%$ & 4.30 & 4.35 & 4.46 \\
\hline
\end{tabular}

As it is seen in Table 2, the tensile and breaking strength and tension elongation have higher values of PVC blends containing calcite modified with stearic acid and compared to the values in PVC blends containing the unmodified calcite.

\section{CONCLUSION}

Limestone is used in different stages of technological process of a large number of industries including PVC industry. PVC blend containing limestone as filler is easily processed by different techniques and final products have superior mechanical properties, especially tensile and breaking strength and tensile elongation. The quality of limestone as filler in PVC industry may be improved modifying its primary mineral calcite with stearic acid. Namely, the modification method provides stronger interaction in the system limestone, i.e. calcite-stearic acid-PVC, as compared to the interaction between two chains of PVC, which does not contain modified filler.

\section{REFERENCES}

[1] J. Pavlica, D. Draškić, Preparation of Nonmetallic Metal Mineral Resources, Faculty of Mining and Geology, Belgrade, 1997;

[2] S. R. Mihajlović, Physico-chemical Moodification of Calcite with Stearic Acid, Doctoral Dissertation, Faculty of Mining and Geology, University of Belgrade, 2011;
[3] S. R. Mihajlović, D. D. Vučinić. Ž. T. Sekulić, S. Z. Milićević, B. M. Kolonja, Mechanism of Stearic Acid Adsorption to Calcite, Powder Technol. 245 (2013), pp. 208-216;

[4] S. Mihajlović, Ž. Sekulić, A. Daković, D. Vučinić, V. Jovanović, J. Stojanović, Surface Properties of Natural Calcite Filler Treated with Stearic Acid, Ceram. Silik. 53 (4) (2009), pp. 268-275;

[5] S. R. Mihajlović, A. S. Daković, Ž. T. Sekulić, D. A. Ileš, M. M. Kragović, Surface Adsorption of Stearic Acid on Natural Calcite, Hem. Ind. 63 (2) (2009), pp. 101-106;

[6] S. R. Mihajlović, Ž. T. Sekulić, D. R. Vučinić, V. D. Jovanović, B. M. Kolonja, Testing the Mechanical Properties of Polyvinyl-chloride with Addition of Modified Calcite as Filler, Hem. Ind. 66 (5) (2012), pp. 787-794;

[7] Technical Encyclopedia, Yugoslav Lexicographical Institute "Miroslav Krleža", Zagreb, 1976;

[8] http://withfriendship.com/user/kalaiku mar/polyvinyl-chloride.php

[9] T. Kovačić, Structure and Characteristics of Polymers, University of Split, Faculty of Chemistry and Technology, 2010;

[10] http:// www.essentialchemicalindustry.org

[11] I. Jovanović, M. Bugarin, S. Magdalinović, Review of Contemporary World Studies on Characteristics of Fly Ash as a Secondary Mineral Resource: Part 1, Mining and Metallurgy Engineering Bor 2/2013, pp. 147-156 


\begin{tabular}{ll}
\hline \hline INSTITUT ZA RUDARSTVO I METALURGIJU BOR & ISSN: 2334-8836 \\
& UDK: 622 \\
\hline \hline
\end{tabular}

\section{PRIMENA KREČNJAKA U INDUSTRIJI POLIVINIL-HLORIDA**}

\section{Izvod}

U radu je prikazan značaj krečnjaka u različitim industrijskim granama sa posebnim osvrtom na upotrebu krečnjaka kao punioca u industriji polivinil-hlorida (PVC). Od svih punilaca koja se koriste u industriji prerade PVC-a, 80 \% su punioci tipa kalcijum karbonata. Punioci se koriste sa ciljem da se poboljšaju različite mehaničke osobine polimera kao što su: zatezna i prekidna svojstva, gustina, tvrdoća, toplotna postojanost, viskozitet $i$ drugo. Najnoviji pravci industrijskog razvoja kao i zahtevi prerađivačke industrije za što kvalitetnijim karbonatnim puniocima uticali su na uvođenje postupka površinskog modifikovanja krečnjaka odnosno kalcita, koji je osnovni konstituent fino mikroniziranog krečnjaka kako bi se poboljšale njegove osobine.

Ključne reči: krečnjak, kalcit, punilac, $P V C$.

\section{UVOD}

Krečnjak se koristi u velikom broju industrijskih grana uključujući i industriju za preradu polivinil hlorida (PVC). Veliku primenu krečnjak je našao u građevinarstvu gde se koristi za pravljenje maltera, betonskih mešavina, u proizvodnji raznih vrsta cementa, kreča i direktno u vidu drobljenog kamena različite krupnoće. Značajan korisnik krečnjaka je metalurgija, gde se krečnjak koristi u aglomeraciji, u visokim pećima i kod Besemerovog postupka topljenja. Hemijska industrija, takođe, koristi značajne količine ove sirovine $\mathrm{u}$ industrijskoj proizvodnji azotnih jedinjenja, celuloze, papira, sode, hlornog kreča, karbida, gume i dr. U poljoprivredi krečnjak se koristi za neutralizaciju kiselih zemljišta i kao dodatak stočnoj hrani. Značajne količine krečnjaka koriste indu- strija šećera, staklarska i keramička industrija. U velikom broju slučajeva pojedine industrijske grane su utvrdile opšte standarde kvaliteta krečnjaka, mada ima slučajeva da korisnici određuju svoje interne zahteve.

Kvalitet krečnjaka (definisan hemijskim sastavom) odnosi se na najmanji sadržaj $\mathrm{CaO}$, odnosno $\mathrm{CaCO}_{3}$ i najveći dozvoljeni sadržaj nečistoća i štetnih komponenti, kao što su: $\mathrm{Fe}_{2} \mathrm{O}_{3}, \mathrm{SiO}_{2}, \mathrm{Al}_{2} \mathrm{O}_{3}, \mathrm{MgO}, \mathrm{P}_{2} \mathrm{O}_{5}$, $\mathrm{TiO}_{2}, \mathrm{MnO}, \mathrm{Cr}_{2} \mathrm{O}_{3}$, sadržaj alkalija, gipsa $\mathrm{i}$ dr. U grupu fizičkih svojstava koje određuju kvalitet krečnjaka spadaju: granulometrijski sastav, tvrdina, nosivost, poroznost, boja i dr. Krečnjak koji se koristi kao punilac u različitim industrijskim granama mora da bude visokokvalitetna fino usitnjena sirovina. Kod proizvoda na bazi krečnjaka

\footnotetext{
* Institut za tehnologiju nuklearnih i drugih mineralnih sirovina, Franše d'Eperea 86, 11000 Beograd, Srbija, e-mail adresa: s.mihajlovic@itnms.ac.rs

** Ovaj rad je nastao kao rezultat istraživanja na Projektu TR 34013: „Osvajanje tehnoloških postupaka dobijanja ekoloških materijala na bazi nemetaličnih mineralnih sirovina" $i$ Projektu TR 34006: „Mehanohemijski tretman nedovoljno kvalitetnih mineralnih sirovina“, koje finansira Ministarstvo prosvete, nauke i tehnološkog razvoja Republike Srbije za period 2011-2014.
} 
najvažnija kvalitativna svojstva su boja (belina) i sjaj. Takođe, fizička struktura mineralne i stenske mase predstavljaju značajan faktor, posebno kada se razmatra sposobnost usitnjavanja ove mineralne sirovine. U okviru ovih zahteva, a za svaku pojedinačnu namenu, odnosno korisnika, utvrđeni su odgovarajući standardi. Postupcima pripreme mineralnih sirovina prerađuju se brojne $\mathrm{Ca}$-karbonatne sirovine, različitog hemijskog i mineralnog sastava, sa ciljem dobijanja velikog broja proizvoda za različite industrijske grane. U literaturi se Ca-karbonatne mineralne sirovine najčešće svrstavaju u industrijske mineralne sirovine, dok ih geolozi razvrstavaju u dolomite i krečnjake, [1].

\section{KREČNJAK - PUNILAC ZA POLIVINIL-HLORID}

Među velikim brojem različitih dodataka koji su neophodni polivinil-hloridu (PVC) kako bi se dobio kvalitetniji definetivni proizvod značajno mesto zauzima skup posebnih dodataka pod zajedničkim nazivom punioci za PVC. Pod pojmom punilac $u$ tehnologiji prerade $\mathrm{PVC}-\mathrm{a}$ podrazumeva se uglavnom vrlo jeftin neorganski materijal, iz čega proizilazi i prvi zadatak, a to je smanjenje cene sveukupne mešavine, odnosno gotovog proizvoda [2]. Mineralni punioci, među koje spada i krečnjak, svoju najveću primenu nalaze upravo u industriji termoplastičnih masa, a posebno kod PVC-a. Industrija za proizvodnju PVC-a postavlja određene zahteve po pitanju kvaliteta koji važe za sve punioce, pa tako i za krečnjak, a to su: da bez ikakvih promena izdrže temperaturu, pritisak i mehaničko naprezanje koji prate preradu PVC-a, neophodno je da se dobro disperguje u PVC-u, da budu što više bele boje, bez nečistoća i stranih materija, ne sme da deluju abrazivno, ne sme da ima više od $0,4 \%$ vlage i ako su punioci za PVC neaktivni potrebno je ipak naglasiti potrebu za njihovom inertnošću i kompatibilnošću sa svim dodacima prisutnim u smesi.
Krečnjak, kao i ostali neorganski punioci, dodaju se PVC-u uvek u formi finog, suvog praha i to u fazi mešanja PVC-a sa svim ostalim dodacima, sa ciljem što bolje i potpunije homogenizacije. Najnoviji pravci industrijskog razvoja kao i zahtevi prerađivačke industrije za što kvalitetnijim karbonatnim puniocima usmerili su ispitivanja ka iznalaženju postupaka kojima se poboljšavaju osobine krečnjaka kao punioca. U cilju dobijanja punioca koji može da poboljša mehaničke osobine PVC proizvoda vrši se površinsko modifikovanje kalcita, koji je osnovni konstituent fino mikroniziranog krečnjaka. Najčešće se od reagenasa za modifikovanje koriste masne kiseline, različite soli masnih kiselina, različita ulja i dr. [2-5]. Krečnjak kod kog je mineral kalcita površinski modifikovan veoma lako se disperguje u polimeru pri čemu se dobija homogena mešavina. Osim toga, krečnjak kod kog je modifikovana površina kalcita pokazuje još neka bolja svojstva u odnosu na krečnjak kod kojih nije modifikovan kalcit, a to su: krečnjak postaje izrazito hidrofoban i tako odbija vodu i vlagu što je posebno važno za svaki punilac; površinskim modifikovanjem kalcita znatno se smanjuje abrazivno dejstvo krečnjaka; ovakvi punioci pokazuju bolja reološka svojstva, veću otpornost na udarac i bolja električna svojstva; upotrebom ovakve vrste punioca dobija se znatno kvalitetnija površina gotovog proizvoda, s obzirom na glatkost, sjaj i njegov izgled. [6]. Treba naglasiti da od svih punioca koja se koriste u industriji prerade PVC-a $80 \%$ od ukupne potrošnje su punioci tipa kalcijum karbonata.

\section{POLIVINIL-HLORID (PVC)}

Polivinil-hlorid (PVC) je više od 70 godina jedan od najvažnijih polimera, čiji je kapacitet proizvodnje oko $20 \%$ ukupne svetske proizvodnje polimera. Postupkom polimerizacije vinil-hlorida dobija se prah od kojeg se daljom preradom proizvode dve vrste PVC-a i to: tvrdi (kruti) PVC i meki (fleksibilni) PVC. Tvrdi PVC se dobija 
preradom polimernog praha bez posebnih dodataka. Providan je, tvrd, žilav i težak za preradu, ali vrlo stabilan na uticaj atmosferskih padavina, vlage i hemikalija. Koristi se npr. za izradu okvira za prozore, kućišta i sl. Meki PVC se dobija preradom polimernog praha uz dodatak plastifikatora. Pri tome se dobija gusta pasta, koja se zagrevanjem pretvara u homogeni gel. Osobine mekog PVC-a zavise od udela plastifikatora. Slabijih je mehaničkih svojstava, manje otporan prema delovanju toplote, atmosferskih padavina i hemikalija u odnosu na tvrdi PVC, ali je savitljiviji, rastegljiviji i lako se prerađuje. Koristi se za izradu izolatora za kablove, medicinskih instrumenata za jednokratnu upotrebu, cevi, rukavica i dr). Meki PVC je providan, pa može da se koristi za pravljenje providnih boca i folija. Generalno se može reći da su osobine polimera uslovljene njihovom unutrašnjom građom, pa su neke njihove osobine slične osobinama čvrstih kristalnih tela, dok su neke slične osobinama tečnosti. Fizičke i mehaničke osobine tvrdog i mekog PVC-a prikazane su u tabeli 1. [7].

Tabela 1. Fizičke i mehaničke osobine PVC-a

\begin{tabular}{llll}
\hline Osobina & \multicolumn{1}{c}{ Jedinica } & \multicolumn{1}{c}{ Tvrdi PVC } & \multicolumn{1}{c}{ Meki PVC } \\
\hline Gustina & $\mathrm{g} / \mathrm{cm}^{3}$ & $1,38-1,55$ & $1,16-1,35$ \\
Zatezna čvrstoća & $\mathrm{MPa}$ & $40-60$ & $10-25$ \\
Produženje pri kidanju & $\%$ & $30-70$ & $250-450$ \\
\hline Čvrstoća na pritisak & $\mathrm{MPa}$ & $55-90$ & $6-12$ \\
Tvrdoća po Shore-u & - & $\mathrm{D} 65-85$ & $\mathrm{~A} 40-100$ \\
\hline Specifični toplotni kapacitet & $\mathrm{J} / \mathrm{K} \mathrm{g}$ & $0,8-1,1$ & $1,3-2$ \\
\hline Toplotna provodljivost & $\mathrm{W} / \mathrm{Kcm}$ & $(15-20) \times 10^{-4}$ & $(13-17) \times 10^{-4}$ \\
\hline Koeficijent toplotnog širenja & $1 / \mathrm{K}$ & $(5-10) \times 10^{-5}$ & $(7-25) \times 10^{-5}$ \\
\hline Temperatura stalne upotrebe & ${ }^{\circ} \mathrm{C}$ & $65-85$ & $50-70$ \\
\hline
\end{tabular}

PVC se danas proizvodi u velikim količinama zbog dobrih mehaničkih i fizičkih svojstava, kao i vrlo raznovrsnih mogućnosti primene. PVC je nezapaljiv, gori samo u prisustvu plamena i hemijski je inertan.
Kompatibilan je sa mnogim aditivima, uključujući punioce, plastifikatore, stabilizatore, klizna sredstva, pigmente, kao i druge polimere. Na slici 1 je prikazan udeo pojedinih dodataka polivinil hloridu [8].

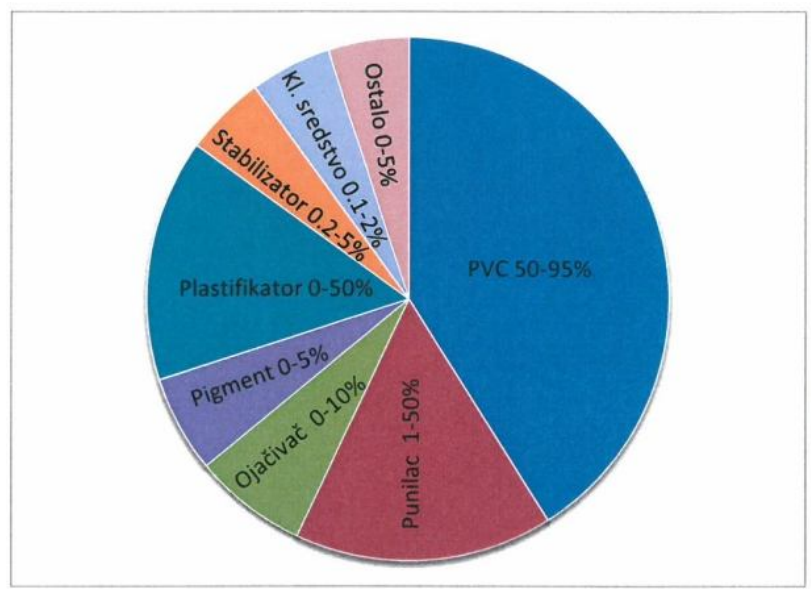

Sl. 1. Udeo pojedinih dodataka u PVC mešavini 
Ovi dodaci omogućavaju da se polivinil hlorid lakše prerađuje različitim tehnikama i da se dobiju proizvodi sa što boljim mehaničkim svojstvima.

\section{PLASTIČNE MASE}

Plastične mase su polimerni materijali u postupku prerade. Pri tome se podrazumeva da je polimerni materijal sve ono što se prerađuje, tj. ono od čega je izrađen gotov proizvod. Takođe, plastičnim masama se nazivaju materijali dobijeni na bazi polimera, koji imaju u nekom stanju plastičnost (uslovi visoke temperature), a koja se potpuno ili delimično gubi pri prelasku $u$ druge temperaturne uslove (niže temperature). Plastičnost tih materijala omogućava da se od njih dobiju proizvodi potrebnog oblika primenom metoda baziranih na plastičnoj deformaciji. Plastične mase se odlikuju time što njihove mehaničke osobine predstavljaju kombinaciju osobina čvrstih tela i tečnosti. Drugim rečima to su čvrsti materijali koji mogu da podležu velikim mehaničkim povratnim deformacijama [9]. Zbog toga plastične mase danas imaju izuzetno veliku primenu u različitim industrijskim granama, kao i u svakodnevnom životu. Posebno je porasla upotreba i proizvodnja sintetičkih termoplastičnih masa - termoplasta (na visokim temperaturama se lako oblikuju, a hlađenjem zadržavaju taj oblik), u koje spada i PVC, kao i njihova upotreba. Na slici 2 je prikazana potrošnja PVC-a u različitim industrijama [10].

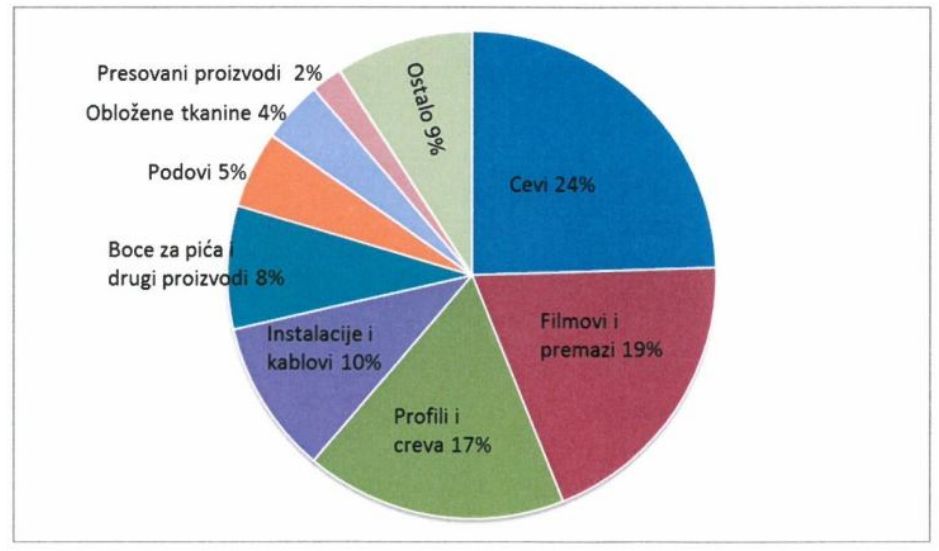

S1. 2. Potrošnja PVC u različitim industrijama

Plastične mase mogu da se sastoje samo od polimera. Međutim, u najvećem broju slučajeva plastične mase predstavljaju višekomponentne sisteme (tzv. polimerne mešavine) u čiji sastav, pored polimera, ulaze sledeće komponente: vezivo, katalizator ili očvršćivač, punilac, plastifikator, bojilo i dr. Plastična masa koju čine samo polimer sa puniocem su najjednostavnija vrsta polimerne mešavine, koja se sastoji iz polimerne osnove (matrice) kao kontinuirane faze i neorganskog punioca dispergovanog $\mathrm{u}$ matrici. Punioci se koriste sa ciljem da se modi- fikuju različite osobine polimera kao što su: zatezna svojstva (zatezna čvrstoća i zatezno izduženje); prekidna svojstva (prekidna čvrstoća i prekidno izduženje); povećava gustinu, modul elastičnosti i savojnu čvrstoću; smanjuje koeficijent toplotnog širenja i puzanje; povećava tvrdoću i toplotnu postojanost; poboljšava kvalitet površine gotovog proizvoda; modifikuje toplotnu i električnu provodljivost; menja svojstva tečenja tako što povećava viskozitet i smanjuje bubrenje ekstrudata; smanjuje zapaljivost i poboljšava mogućnost bojenja plastike. 
Mehaničke osobine plastičnih masa imaju veliki značaj kako u procesu prerade tako i za definisanje kvaliteta gotovih proizvoda. Kod plastičnih masa najčešće se statičkim ispitivanjima mehaničkih osobina određuju: zatezna čvrstoća i zatezno izduženje; prekidna čvrstoća i prekidno izduženje. Osobine pri zatezanju su od primarne važnosti, jer daju informacije o maksimumu dozvoljenog opterećenja do loma plastične mase i konačnog pucanja. U plastičnoj masi koju čini polimer bez punioca lom nastaje na mestu na kom je struktura najslabija, odnosno na mestu stvaranja najvećeg naprezanja kao posledice procesa deformacije. Lokalna pukotina se dalje širi kroz ceo materija. Na slici 3 su prikazani lanci polivinil hlorida koji su međusobno povezani Van der Valsovim vezama koje se kidaju pri delovanju sile istezanja na plastičnu masu [2].

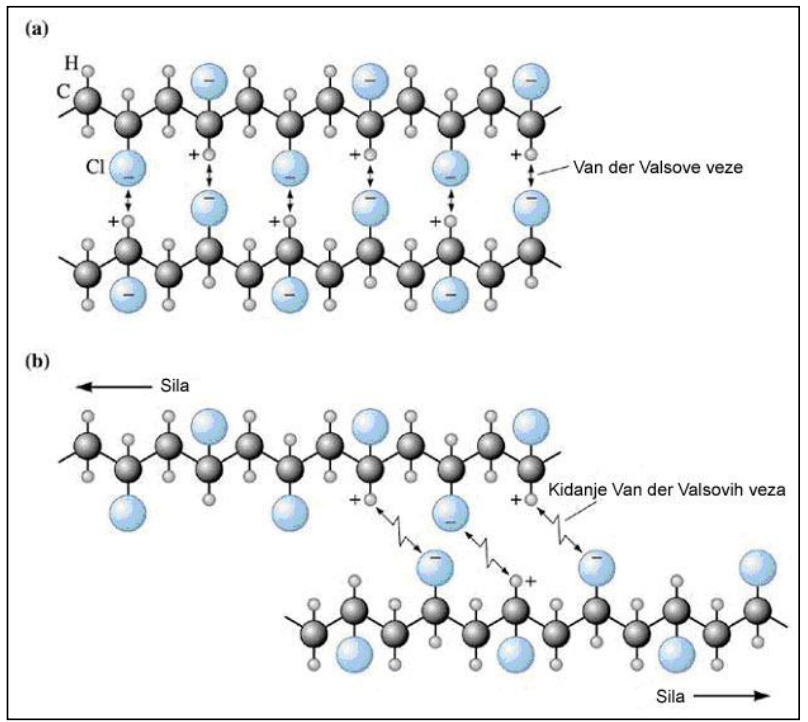

Sl. 3. Šmatski prikaz međumolekulskih veza kod PVC-a: a) Van der Valsove veze između dva lanca PVC-a; b) kidanje Van der Valsovih veza između dva lanca PVC-a pod dejstvom sile istezanja

U plastičnoj masi koju čini polimer sa puniocem lom može da započne u samoj matrici, na međupovršini polimer/punilac ili unutar aglomerata formiranih u puniocu. Zatezno naprezanje polimerne mešavine zavisi od njene mikrostrukture, uključujući međupovršinsku strukturu na granici polimer/punilac, pošto se opterećenje prenosi sa jedne faze na drugu. Takođe, osobine polimerne mešavine pri naprezanju su određene oblikom i veličinom čestica punioca, kao i njihovim prostornim rasporedom $\mathrm{u}$ matrici, tj. polimeru. Generalno se može reći da punilac tipa kalcijum karbonata svojim prisustvom doprinosi jačoj interakciji između dva lanca PVC-a. Ali dodatkom krečnjaka kod kog je kalcit, kao dominantni mineral, modifikovan stearinskom kiselinom polimernoj mešavini, obezbeđuje se još jača interakcija u sistemu krečnjak odnosno kalcit-stearinska kiselina - PVC što kao rezultat ima poboljšanje mehaničkih osobina gotovog proizvoda [2, 6]. U tabeli 2 su date vrednosti nekih od mehaničkih osobina PVC mešavina koje sadrže čist krečnjak (K) kao punilac $(\mathrm{PVC}+\mathrm{K})$ i modifikovani krečnjak (PVC+KM-1.5 i PVC+KS-3). Oznaka M se odnosi na ,mokri“ postupak modifikovanja kalcita, S na ,suvi“" postupak, dok broj predstavlja koncentraciju stearinske kiseline koja 
je upotrebljena za modifikovanje izraženu u $\%$. Kod oba postupka su uzete one koncen- tracije pri kojima je ostvarena potpuna pokrivenost minerala stearinskom kiselinom.

Tabela 2. Mehaničke osobine PVC mešavina

\begin{tabular}{lcccc}
\hline Mehaničke osobine & Jedinica & PVC+K & PVC+KM-1.5 & PVC+KS-3 \\
\hline Zatezna čvrstoća & $\mathrm{MPa}$ & 52,70 & 54,20 & 53,20 \\
Prekidna čvrstoća & $\mathrm{MPa}$ & 36,50 & 38,20 & 37,90 \\
Zatezno izduženje & $\%$ & 4,30 & 4,35 & 4,46 \\
\hline
\end{tabular}

Kao što se vidi u tabeli 2 zatezna i prekidna čvrstoća i zatezno izduženje imaju veće vrednosti kod PVC mešavine koja sadrži kalcit modifikovan stearinskom kiselinom u odnosu na vrednosti kod PVC mešavine koja sadrži nemodifikovani kalcit.

\section{ZAKLJUČAK}

Krečnjak se koristi u različitim fazama tehnološkog procesa velikog broja industrijskih grana uključujući i industriju PVC-a. PVC mešavina koja sadrži krečnjak kao punilac se lakše prerađuje različitim tehnikama i gotovi proizvodi imaju bolja mehanička svojstva prvenstveno zateznu i prekidnu čvrstoću i zatezno izduženje. Kvalitet krečnjaka kao punioca u industriji PVC-a se može poboljšati postupkom modifikovanja njegovog osnovnog minerala kalcita stearinskom kiselinom. Naime, postupkom modifikovanja se obezbeđuje jača interakcija u sistemu krečnjak odnosno kalcit-stearinska kiselina - PVC, u odnosu na interakciju između dva lanca PVC-a koji ne sadrži modifikovani punilac.

\section{LITERATURA}

[1] J. Pavlica, D. Draškić, Priprema nemetaličnih mineralnih sirovina, Rudarskogeološki fakultet, Beograd, 1997.

[2] S. R. Mihajlović, Fizičko-hemijsko modifikovanje kalcita stearinskom kiselinom, Doktorska disertacija, Rudarsko-geološki fakultet Univerziteta u Beogradu, 2011.
[3] S. R. Mihajlović, D. D. Vučinić. Ž. T. Sekulić, S. Z. Milićević, B. M. Kolonja, Mechanism of stearic acid adsorption to calcite, Powder Technol. 245 (2013), str. 208-216.

[4] S. Mihajlović, Ž. Sekulić, A. Daković, D. Vučinić, V. Jovanović, J. Stojanović, Surface properties of natural calcite filler treated with stearic acid, Ceram. Silik. 53 (4) (2009), str. 268275.

[5] S. R. Mihajlović, A. S. Daković, Ž. T. Sekulić, D. A. Ileš, M. M. Kragović, Površinska adsorpcija stearinske kiseline na prirodnom kalcitu, Hem. Ind. 63 (2) (2009), str. 101-106.

[6] S. R. Mihajlović, Ž. T. Sekulić, D. R. Vučinić, V. D. Jovanović, B. M. Kolonja, Ispitivanje mehaničkih osobina polivinil-hlorida sa dodatkom modifikovanog kalcita kao punioca, Hem. Ind. 66 (5) (2012), str. 787-794

[7] Tehnička enciklopedija, Jugoslovenski leksikografski zavod „Miroslav Krleža“", Zagreb, 1976.

[8] http://withfriendship.com/user/kalaiku mar/polyvinyl-chloride.php

[9] T. Kovačić, Struktura i svojstva polimera, Sveučilište u Splitu, Kemijskotehnološki fakultet, 2010.

[10] http:// www.essentialchemicalindustry.org

[11] I. Jovanović, M. Bugarin, S. Magdalinović, Pregled savremenih svetskih istraživanja o karakteristikama letećeg pepela kao sekundarne mineralne sirovine; Deo 1, Mining and Metallurgy Engineering Bor 2/2013, str. 157-166 